\title{
First estimates of potential lifespan of giant armadillo (Priodontes maximus) in the wild
}

\author{
Arnaud Leonard Jean Desbiez ${ }^{\mathrm{A}, \mathrm{B}, \mathrm{C}, 1}$, Duston Larsen $^{\mathrm{D}}$, Gabriel Favero \\ Massocato $^{\mathrm{A}, \mathrm{C}, \mathrm{E}}$, Nina Attias ${ }^{\mathrm{A}}$, Danilo Kluyber ${ }^{\mathrm{A}, \mathrm{C}, \mathrm{F}}$ \& Damián I. Rumiz ${ }^{\mathrm{C}}$ \\ A Instituto de Conservação de Animais Silvestres (ICAS), CEP 79040-290 Campo Grande, Mato Grosso do Sul, Brasil \\ ${ }^{\text {B }}$ Royal Zoological Society of Scotland (RZSS), Murrayfield, Edinburgh, EH12 6TS, United Kingdom \\ C Instituto de Pesquisas Ecológicas (IPÊ), Nazaré Paulista, CEP 12960-000, São Paulo, Brasil \\ ${ }^{D}$ San Miguelito Jaguar Conservation Ranch, Santa Cruz, Bolivia \\ ${ }^{E}$ Houston Zoo, 6200 Hermann Park Drive, Houston, TX 77030, USA \\ F Naples Zoo at Caribbean Gardens, Naples, FL 34102, USA \\ ${ }^{\mathrm{G}}$ Museo de Historia Natural Noel Kempff Mercado and Fundación Simón I. Patiño, Santa Cruz de la Sierra, Bolivia \\ 1Corresponding author. E-mail: adesbiez@hotmail.com
}

\begin{abstract}
This paper reports on results from two camera trapping initiatives where individual giant armadillos, Priodontes maximus, were identified and monitored over multiple years, thus providing insights into their potential lifespan. One camera trap array was located in the Brazilian Pantanal, in Mato Grosso do Sul, where an adult female was first identified in October 2011 and documented again in January 2021, leading us to estimate her age as at least 17.5 years old. The other camera trap array was located at the border of the Chaco alluvial plains in Santa Cruz, Bolivia, where a female was first registered in June 2004 and then again in January 2019; we estimate her age to be at least 18 years old. While recognizing that these two data points are insufficient to evaluate life expectancy of the species, this paper does provide the first evidence of potential lifespan of wild P. maximus. It also shows that both females were documented in the same area after intervals of 10 and 15 years, providing new clues on long-term site fidelity. This paper highlights the importance of long-term camera trap arrays for the study of cryptic nocturnal mammals that are long lived and occur at low densities.
\end{abstract}

Keywords: Bolivia, Brazil, camera traps, Cingulata, individual identification, maximum lifespan

Primeras estimaciones de longevidad potencial del armadillo gigante (Priodontes maximus) en la naturaleza

Resumen Este artículo informa sobre los resultados de dos iniciativas de fototrampeo en las que se identificaron y monitorearon individuos de armadillo gigante, Priodontes maximus, a lo largo de los años, y que proporcionan información sobre su longevidad potencial. Un conjunto de cámaras trampa se ubicó en el Pantanal brasileño, en Mato Grosso do Sul, donde una hembra adulta fue identificada por primera vez en octubre de 2011 y documentada nuevamente en enero de 2021, por lo que se estima que tiene al menos 17,5 años de edad. El otro conjunto de cámaras trampa se ubicó en el límite de las llanuras aluviales del Chaco en Santa Cruz, Bolivia, donde se registró una hembra por primera vez en junio de 2004 y luego nuevamente en enero de 2019, por lo que su edad se estimó en más de 18 años. Si bien reconocemos que estos dos datos son insuficientes para evaluar la esperanza de vida de la especie, este documento proporciona la primera evidencia de la longevidad potencial de $P$. maximus silvestres. También muestra que ambas hembras fueron documentadas en la misma área después de 10 o 15 años, proporcionando nuevas pistas sobre la fidelidad del sitio a largo plazo. Este artículo destaca la importancia del seguimiento con cámaras trampa a largo plazo para el estudio de mamíferos nocturnos crípticos que tienen una vida larga y se encuentran en densidades bajas.

Palabras clave: Bolivia, Brasil, Cingulata, identificación individual, longevidad máxima, trampas cámara 


\section{INTRODUCTION}

Longevity (life expectancy at birth), maximum lifespan, and reproductive lifespan are key parameters used to describe the population dynamics of wild animal populations (Radchuk et al., 2016; Lacy, 2019). Reproductive lifespan is also employed for estimation of a species generation length, which in turn is used for extinction risk assessment by the IUCN Red List (Fung \& Waples, 2017; IUCN, 2019). While well explored theoretically, these parameters have rarely been documented in wild animals and are often based on estimates (Pe'er et al., 2013; Morrison et al., 2016). Estimates are often guessed or based on animals living under human care, which may artificially inflate the estimates (Pe'er et al., 2013; Lacy, 2019). Long-term studies in the wild are necessary to increase the accuracy of these parameter estimates, especially for species that do not possess morphological and anatomical features that allow age estimation. However, these longterm studies are overall rare and usually focus on animals that can be relatively easily observed (e.g., Breuer et al., 2009).

The giant armadillo Priodontes maximus Kerr, 1792 (Mammalia: Cingulata) is the largest living species of Cingulata, with adults measuring up to $1.5 \mathrm{~m}$ and weighing up to $60 \mathrm{~kg}$ (Carter et al., 2016; Desbiez et al., 2019). This cryptic species is naturally rare, but widely distributed throughout 11 countries in South America, where it occupies habitats ranging from tropical forest to open savanna (Abba \& Superina, 2010). Giant armadillos are myrmecophagous, have extensive home ranges, are solitary, nocturnal, and fossorial, spending all day in their deep burrows (Eisenberg \& Redford, 1999; Silveira et al., 2009; Desbiez \& Kluyber, 2013; Desbiez et al., 2020a; Desbiez et al., 2021). Furthermore, this species is notoriously difficult to capture and study in the wild (Silveira et al., 2009; Carter et al., 2016; Quiroga et al., 2017; Desbiez et al., 2020a). Currently, there are no estimates of maximum lifespan for P. maximus, although it is reported that one captive individual lived 16 years (Carter et al., 2016).

Camera trapping is one of the main tools used to advance P. maximus research (Noss et al., 2004; Porfirio et al., 2012; Desbiez \& Kluyber, 2013; Aya-Cuero et al., 2017; Quiroga et al., 2017; Massocato \& Desbiez, 2017; Esteves et al., 2018; Desbiez et al., 2020b,c; Di Blanco et al., 2020; Fontes et al., 2020). Records obtained by camera traps can allow the individual identification of $P$. maximus if properly examined (Noss et al., 2004; Massocato \& Desbiez, 2019). This paper reports on results from two camera trapping initiatives where giant armadillos were individually identified and monitored over multiple years, providing insights into the potential lifespan of P. maximus.

\section{MATERIALS AND Methods}

Fazenda Baia das Pedras, Brazil. A long-term study on $P$. maximus is being carried out since July 2010 on private cattle ranches $\left(19^{\circ} 16^{\prime} \mathrm{S}, 55^{\circ} 42^{\prime} \mathrm{W}\right)$ in the Brazilian Pantanal (Nhecolândia subregion; Desbiez et al., 2020a) of Mato Grosso do Sul. The study includes the use of both camera trapping and animal capture for the placement of telemetry monitoring devices (see Desbiez et al., 2020c). Camera traps have been installed following two different approaches (Desbiez et al., 2020a,c): (1) Cameras were placed in front of active giant armadillo burrows. This allowed us to detect not only the individuals that built and used the burrows but also passing individuals that often inspected scent marks left in the burrow entrance. (2) Two camera trap arrays were installed in areas known to be used by several telemetry-monitored individuals. From July 2016 to January 2017, we established one array $(\mathrm{n}=75$ camera sites) in an area where a cluster of 12 known individual $P$. maximus had been captured and monitored since the beginning of the project (2010). In 2020, a second array of 10 cameras was placed in the home range of one of the first giant armadillos monitored by the project (TC-04), following the methods used to install the previous array, as described in Desbiez et al. (2020c).

San Miguelito Jaguar Conservation Ranch, Bolivia. This cattle ranch (and tourist lodge) lies at the border of the Chaco alluvial plains and the Precambrian shield, in the lowlands of Santa Cruz. Its owner has hosted wildlife studies since the 1990s at a research camp by the San Julián river $\left(17^{\circ} 05^{\prime} \mathrm{S}\right.$, $\left.61^{\circ} 47^{\prime} \mathrm{W}\right)$, which is surrounded by wetlands, palm savannas, and dry forests (see habitat and fauna description in Rumiz et al., 2002; Rivero et al., 2005). In order to study jaguars and other terrestrial mammals, two 60-day intensive camera trap surveys were conducted around this camp in 2002 and 2004. In addition, a non-systematic monitoring effort has been conducted with a few cameras since 2017 to date. The survey in 2002 (20 September to 20 November; Noss et al., 2004) had 22 camera sites with paired cameras covering a polygon of $24 \mathrm{~km}^{2}$, and produced three records of two female giant armadillos. The survey in 2004 ( 5 June to 8 August; Arispe et al., 2005) had 25 camera sites spread over $54 \mathrm{~km}^{2}$, and resulted in 11 records of three females and two males. The recent records, from 2018 and 2019, allowed us to identify two P. maximus individuals.

\section{Individual identification}

Individual $P$. maximus were identified using morphological characteristics following Massocato \& Desbiez (2019) and Noss et al. (2004). Characteristics included: (1) cephalic scale pattern (the pattern of scales displayed on the animal's head is unique and varies in shape, number, and 
arrangement); (2) tail markings (individuals may have dark scales along the tail interspersed among the lighter scales); (3) flank scale pattern (the number of light scales between the edge of the carapace and the dark scales, as well as indentations and shapes formed by the light and dark scales are often used to identify individuals); (4) lighter scales above the base of the tail (the width and shape of the light band between the base of the tail and the darker scales at the upper part of the carapace varies between individuals); and (5) scale coloration on the hind limbs (some individuals have a dark ankle brace on the upper hind limb that may be of varying shape or size on each side or even absent in some individuals). Natural marks, such as scars, also were used.

\section{RESULTS}

\section{Fazenda Baia das Pedras, Brazil}

TC-04 is an adult female, first captured in October 2011 and later recorded by camera traps in August 2016 and January 2021 (FIG. 1). In 2011, during its first capture examination, TC-04 showed signs of having previously bred, due to her elongated vulva that measured about $7 \mathrm{~cm}$ and teats over $2.5 \mathrm{~cm}$ (Desbiez et al., 2019; Massocato \& Desbiez, 2019). A recent genetic study that is part of our research program showed that another individual (TC-10) captured in an area near hers was her offspring (N.T. Rodrigues, unpublished data). TC-10 was estimated to be between 2.5 and 3.5 years old when captured in June 2013, based on his body
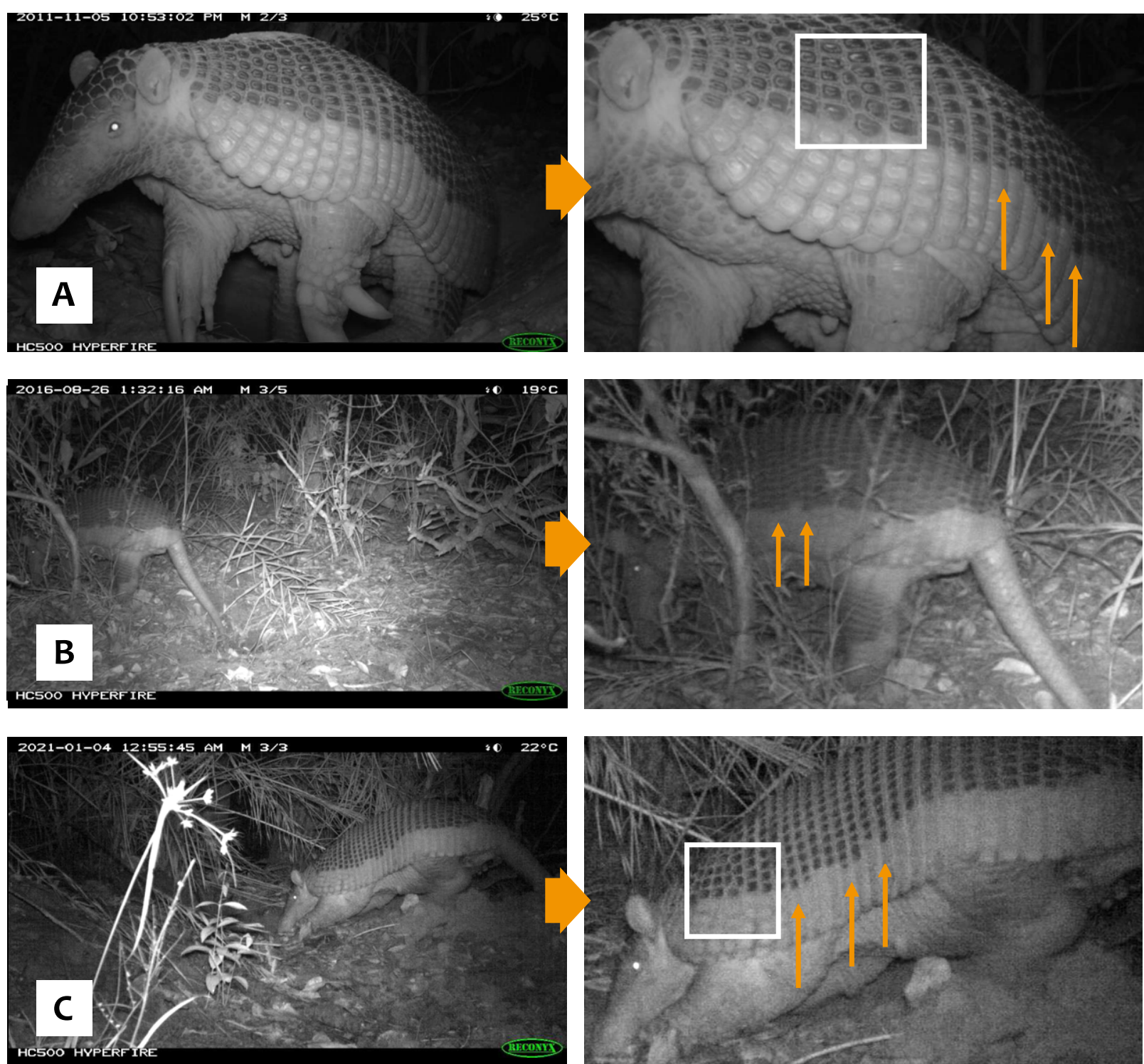

FIGURE 1. Identification of the individual giant armadillo (Priodontes maximus; TC-04) on three occasions at Baia das Pedras ranch, Brazil. On the left are the original camera trap images with the recorded date, and on the right the photos are augmented with arrows and highlighted areas that point to the unique patterns of white and dark scales used for individual identification. A. Photo taken in November, 2011. B. Photo in August, 2016. C. Photo in January, 2021. 
mass and penis size (following Luba et al., 2020). The age estimates for TC-10 are also based on interbreeding interval and length of parental care estimates for the species (Desbiez et al., 2020b). When first captured, TC-04 was intensively monitored with camera traps that were placed in front of all the burrows she was known to use. Nevertheless, TC-10 was never caught in these traps. Hence, we can conclude that TC-04 had given birth to TC-10 more than 18 months before, as cubs are weaned between 11 and 12 months of age and only use their mother's burrows until they are approximately 1.5 years old (Desbiez et al., 2020b). Therefore, the intense parental care period was likely over when we first caught TC-04, because otherwise we would have recorded TC-10 using TC-04's burrows (Desbiez et al., 2020b). Furthermore, P. maximus gestation is five months long (Desbiez et al., 2020b), and individuals are estimated to reach sexual maturity between 6.5 to 8 years of age (Luba et al., 2020). Hence, TC-04 was at least 8.5 to 10 years old when first captured, assuming she reproduced right after achieving sexual maturity and that TC-10 resulted from her first breeding event. If not, then it is possible TC-04 could be even older. TC-04 was recorded alive by our first camera trap array in 2016 (Desbiez et al., 2020c), and recaptured in our new array in January 2021. Based on the foregoing, this latter record leads us to conclude that she is at least 17.5 years old.

\section{San Miguelito Jaguar Conservation Ranch, Bolivia}

The female F1 was first identified on 21 June 2004 and last identified in January 2019 (FIG. 2). It is challenging to gauge the age of F1 when she was first documented in the camera trap because small adults and large subadults can present similar body mass and size (Desbiez et al., 2019). Female adults and sub-adults can be distinguished by the size of teats or vulva (Desbiez et al., 2019) and, while it is generally possible to make these distinctions from camera trap records (Massocato \& Desbiez, 2019), it was not possible to do so for the 2004 record of F1. Therefore, while the image presents an animal with a body resembling that of an adult, this female could have been as young as 3 or 4 years old. However, because this female was registered in the same location after 15 years, we can assume that in 2004 she was already a resident individual. In the Pantanal, the Giant Armadillo Conservation Program has registered two young subadult females (TC-21 and TC-22) that dispersed from their natal areas when they were estimated to be between 4 to 6 years of age. Therefore, a conservative guess for the age of $F 1$ would be that she was at least 4 years old when first recorded in 2004. This would mean that in 2019 she was at least 18 years old.

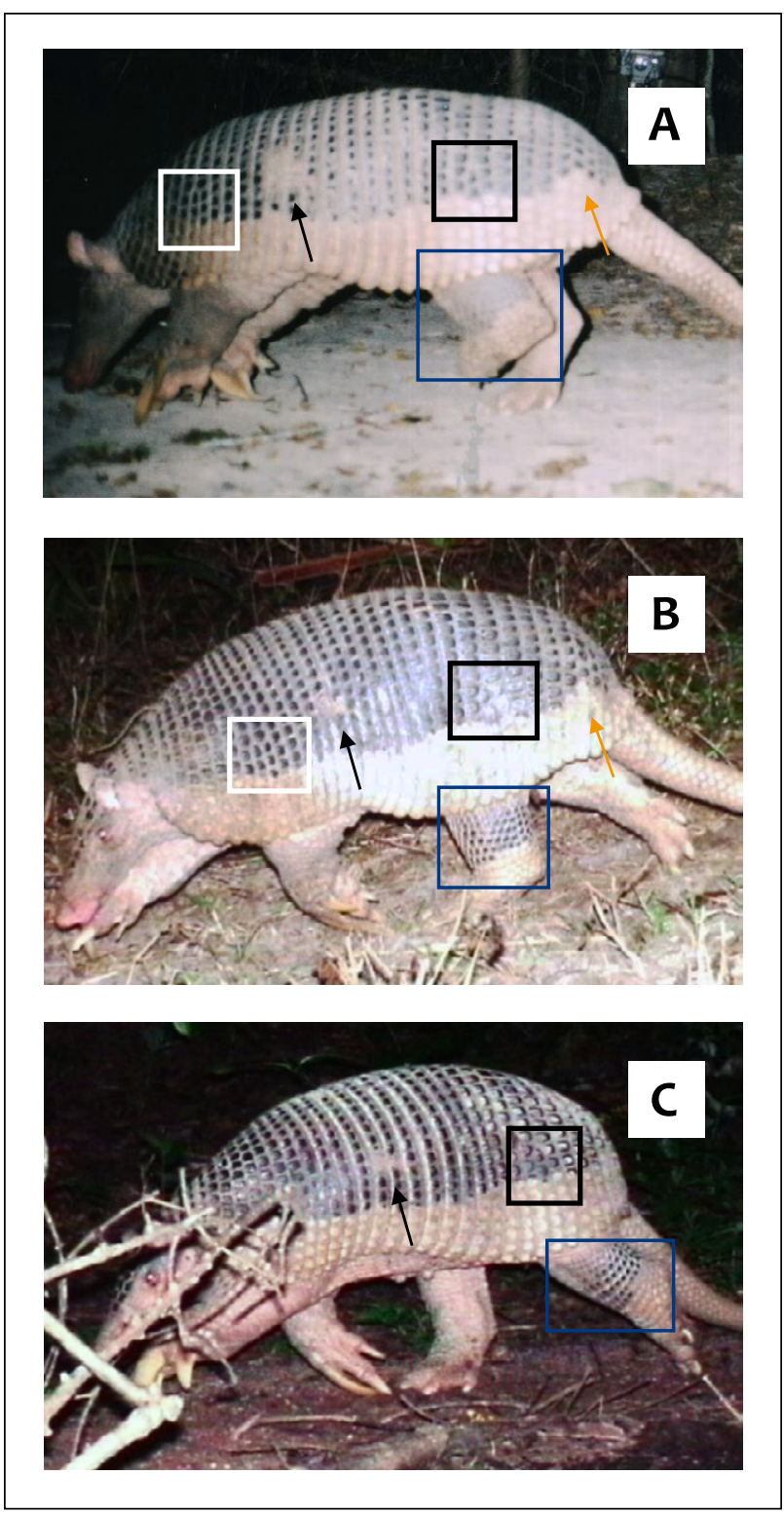

FIGURE 2. Identification of the individual giant armadillo (Priodontes maximus; F1) on three occasions at San Miguelito Jaguar Conservation Ranch, Bolivia. A. Photo in June, 2004. B. Photo in August, 2018. C. Photo in January, 2019. The arrows and highlighted areas point to the characters used for individual identification, which include areas where the armor is discolored, as well as unique patterns of white and dark scales on the armor and hind leg.

\section{DISCUSSION}

Here, we provide the first long-term records of range-resident wild giant armadillos, thus allowing us to estimate their potential lifespan.

To age giant armadillos and gather data on potential lifespan, we must rely on capture/recapture and individual markings. Since 2010, the Giant Armadillo Conservation Program has captured a total of 34 individual giant armadillos and has shown that it is possible to distinguish subadults and adults through morphometric measures (Desbiez 
et al., 2019), as well as by inspecting their genitals (Massocato \& Desbiez, 2019; Luba et al., 2020). However, once animals have reached full adult size and sexual maturity, it is impossible to guess their age based on these morphological characters. During our research, we have re-captured adult animals and, depending on the season, the same animal can present slight physical differences. For example, weight may vary by one to three $\mathrm{kg}$ at different times of the year (Desbiez et al., 2019). In addition, the appearance and impressions of wear on the carapace scales, and even claws, can be different among captures (A. Desbiez, pers. obs.).

Age of mammals is often evaluated through morphological indices such as growth annuli, secondary physical characteristics related to age, and growth models (Eaton \& Link, 2011). Luba et al. (2019) used body mass and penis size to estimate the age of male $P$. maximus until they reached full body size and sexual maturity. Nevertheless, to age adult individuals we currently must rely on recapture events and individual markings. When first captured, we believe TC-04 was at least 8.5 years old, but she could have been 20 years old, based on the tools for age estimation we have today. The same rationale can be applied to $\mathrm{F} 1$. Therefore, our age estimates for TC-04 and F1 are both conservative, but show that giant armadillos can live nearly 20 years in the wild, and likely beyond that.

We recognize that evaluating life expectancy, maximum lifespan or reproductive lifespan requires much more data than these two examples. Mayne et al. (2020) highlight how using point values may inflate estimates due to outliers or, on the contrary, not determine the appropriate age due to undersampling. These authors suggest estimating life expectancy from a population's full dataset, or life table, rather than a point value from a single longlived individual to avoid such problems. However, this implies that a methodology of ageing exists for a particular species, either through individual markings or morphological indices that allow building a life table (Eaton \& Link, 2011), or it requires access to long-term population data, neither of which are currently available for P. maximus.

There are a number of reasons to suspect a long lifespan for P. maximus. First, recent publications on giant armadillos highlight the low population growth rate of the species, with sexual maturity occurring around 6.5 to 8 years of age (Luba et al., 2020), and long parental care; the only documented interbirth interval is three years (Desbiez et al., $2020 \mathrm{~b})$. These traits are usually associated with K-selected species that are typically long-lived (Pianka, 1970). While the $\mathrm{r} / \mathrm{K}$ selection paradigm has been displaced by demographic models, these general traits still hold true. Second, age at maturity also is usually proportional to adult lifespan (Magalhães et al., 2007), and giant armadillos reach sexual maturity late compared to other species of armadillo (Luba et al., 2020). Third, larger animals live longer (Speakman, 2005). Finally, in captivity, species of Xenarthra generally live longer, with records of armadillos (Cingulata) reaching 28 years, anteaters (Pilosa, Vermilingua) 30 years, and sloths (Pilosa, Folivora) 40 years (ZIMS, 2021). For all these reasons, we therefore predict the $P$. maximus lifespan to be $\geq 20$ years.

Another important piece of data revealed by our camera trap images is that both $P$. maximus females were recorded using the same area many years after being first documented. Desbiez et al. (2020a) reported on the spatial ecology of 23 P. maximus and argued that movement patterns of both sexes were indicative of site fidelity. Hence, although we cannot ensure that these individuals remained in these areas during all the years they were not monitored/ detected, the results from this study reinforce the suggestion of long-term site fidelity made by Desbiez et al. (2020a).

While we recognize the limitations of the data presented, these results are unique and important for wild P. maximus. We intend to continue the longterm monitoring of $P$. maximus at Baia das Pedras and the San Miguelito Jaguar Conservation Ranch, and hope to be able to report on TC-04 and F1 over the next five years. Most importantly, we hope to be able to document if they are still breeding. The findings of our study reinforce the view that long-term camera trap studies are essential tools for the study of cryptic nocturnal mammals that are long-lived and occur at low densities. These studies can provide crucial insights into certain life history parameters, so long as individual identification is possible.

\section{ACKNOWLEDGEMENTS}

We are grateful to the owners of the Fazenda Baía das Pedras for their hospitality, generous support, and permission to work on their land. This study is part of the Giant Armadillo Conservation Program, which benefited from multiple grants, mostly from zoos in North America and Europe, listed at https://www.giantarmadillo.org/partners. We want to thank the late Ronald Larsen for encouraging wildlife studies at San Miguelito ranch and the former Wildlife Conservation Society/Museo NKM team (A. Noss, R. Arispe, C. Venegas, S. Angulo, K. Rivero) for sharing the original camera trap pictures for comparison with the most recent surveys. This study was authorized by the Bolivian biodiversity authority in the framework of the jaguar conservation research project by Museo NKM. We are grateful to William J. Loughry and two anonymous reviewers for improving the quality of this manuscript. 


\section{REFERENCES}

Abba, A.M. \& M. Superina. 2010. The 2009/2010 armadillo Red List assessment. Edentata 11: 135-184. https://doi.org/10.5537/020.011.0203

Arispe, R., D. Rumiz \& C. Venegas. 2005. Second camera-trap survey for jaguars (Panthera onca) and other mammals at San Miguelito Ranch. June - August/2004. WCS - Museo NKM Report. Santa Cruz, Bolivia. 22 pp.

Aya-Cuero, C., A. Rodríguez-Bolaños \& M. Superina. 2017. Population density, activity patterns, and ecological importance of giant armadillos (Priodontes maximus) in Colombia. Journal of Mammalogy 98: 770-778. https://doi.org/10.1093/jmammal/gyx006

Breuer, T., M. B. N. Hockemba, C. Olejniczak, R.J. Parnell \& E.J. Stokes. 2009. Physical maturation, life-history classes and age estimates of free-ranging Western Gorillas-insights from Mbeli Bai, Republic of Congo. American Journal of Primatology 71: 106-119. https://doi.org/10.1002/ajp.20628

Carter, T.S., M. Superina \& D. M. Leslie. 2016. Priodontes maximus (Cingulata: Chlamyphoridae). Mammalian Species 48: 21-34. https://doi.org/10.1093/mspecies/ sew002

Desbiez, A.L.J. \& D. Kluyber. 2013. The role of giant armadillos (Priodontes maximus) as physical ecosystem engineers. Biotropica 45: 537-540. https://doi. org/10.1111/btp.12052

Desbiez, A.L.J., G.F. Massocato, D. Kluyber, C.N. Luba \& N. Attias. 2019. How giant are giant armadillos? The morphometry of giant armadillos (Priodontes maximus Kerr, 1792) in the Pantanal of Brazil. Mammalian Biology 95: 9-14. https://doi.org/10.1016/j. mambio.2018.12.007

Desbiez, A.L.J., G.F. Massocato, D. Kluyber, L.G.R. Oliveira-Santos \& N. Attias. 2020a. Spatial ecology of the giant armadillo (Priodontes maximus) in Midwestern Brazil. Journal of Mammalogy 101: 151-163. https://doi.org/10.1093/jmammal/gyz172

Desbiez, A.L.J., G.F. Massocato \& D. Kluyber. 2020b. Insights into giant armadillo (Priodontes maximus Kerr, 1792) reproduction. Mammalia 84: 283-293. https:// doi.org/10.1515/mammalia-2019-0018

Desbiez, A.L.J., G.F. Massocato, N. Attias \& M. Cove. 2020c. Comparing density estimates from a short-term camera trap survey with a long-term telemetry study of giant armadillos (Priodontes maximus). Mastozoología Neotropical 27: 1-18. https://doi.org/10.31687/ saremMN.20.27.2.0.08

Desbiez, A.L.J., D. Kluyber, G.F. Massocato \& N. Attias. 2021. Methods for the characterization of activity patterns of elusive species: the giant armadillo in the Brazilian Pantanal. Journal of Zoology 315: 301-312. https://doi.org/10.1111/jzo.12921

Di Blanco, Y.E., A.L.J. Desbiez, D. di Francescantonio \& M.S. Di Bitetti. 2020. Excavations of giant armadillos alter environmental conditions and provide new re- sources for a range of animals in their southernmost range. Journal of Zoology 311: 227-238. https://doi. org/10.1111/jzo.12782

Eaton, M.J. \& W.A. Link. 2011. Estimating age from recapture data: integrating incremental growth measures with ancillary data to infer age-at-length. Ecological Applications 21: 2487-2497. https://doi. org/10.1890/10-0626.1

Eisenberg, J.F. \& K.H. Redford. 1999. Mammals of the Neotropics, Volume 3. The central Neotropics: Ecuador, Peru, Bolivia, Brazil. The University of Chicago Press, Chicago. 624 pp.

Esteves, C.F., D.H. Homem, R. Bernardo \& E.F. Lima. 2018. Notes on giant armadillo Priodontes maximus (Cingulata: Chlamyphoridae) distribution and ecology in Eucalyptus plantation landscapes in eastern Mato Grosso do Sul State, Brazil. Edentata 19: 47-56. https://doi.org/10.2305/IUCN.CH.2018.Edentata19-1.6.en

Fontes, B.L. et al. 2020. The local extinction of one of the greatest terrestrial ecosystem engineers, the giant armadillo (Priodontes maximus) in one of its last refuges in the Atlantic Forest will be felt by a large vertebrate community. Global Ecology and Conservation 24: e01357. https://doi.org/10.1016/j.gecco.2020.e01357

Fung, H.C. \& R.S. Waples. 2017. Performance of IUCN proxies for generation length. Conservation Biology 31: 883-893. https://doi.org/10.1111/cobi.12901

IUCN Standards and Petitions Committee. 2019. Guidelines for using the IUCN Red List categories and criteria. Version 14. Prepared by the Standards and Petitions Committee. http://www.iucnredlist.org/ documents/RedListGuidelines.pdf. Accessed on 30 March 2021.

Lacy, R.C. 2019. Lessons from 30 years of population viability analysis of wild populations. Zoo Biology 38: 67-77. https://doi.org/10.1002/zoo.21468

Luba, C.N., et al. 2020. Size matters: penis size, sexual maturity and their consequences for giant armadillo conservation planning. Mammalian Biology 100: 621630. https://doi.org/10.1007/s42991-020-00065-3

Magalhães, J.P., J. Costa \& G. M. Church. 2007. An analysis of the relationship between metabolism, developmental schedules, and longevity using phylogenetic independent contrasts. The Journals of Gerontology: Series A 62: 149-160. https://doi.org/10.1093/ gerona/62.2.149

Massocato, G.F. \& A.L.J. Desbiez. 2017. Presença e importância do tatu-canastra, Priodontes maximus (Kerr, 1792), na maior área protegida do leste do Estado de Mato Grosso do Sul, Brasil. Edentata 18: 26-33. https:// doi.org/10.2305/IUCN.CH.2017.Edentata-18-1.4.en

Massocato, G.F. \& A.L.J. Desbiez. 2019. Guidelines to identify individual giant armadillos, Priodontes maximus (Kerr, 1792), through camera traps. Edentata 20: 1-16. https://doi.org/10.2305/IUCN.CH.2019. Edentata-20-1.2.en 
Mayne, B., O. Berry \& S. Jarman. 2020. Redefining life expectancy and maximum lifespan for wildlife management. Austral Ecology 45: 855-857. https://doi. org/10.1111/aec.12931

Morrison, C., C. Wardle \& J. G. Castley. 2016. Repeatability and reproducibility of population viability analysis (PVA) and the implications for threatened species management. Frontiers in Ecology and Evolution 4: 98. https://doi.org/10.3389/fevo.2016.00098

Noss, A.J., R. Peña \& D.I. Rumiz. 2004. Camera trapping Priodontes maximus in the dry forests of Santa Cruz, Bolivia. Endangered Species Update 21: 43-52.

Pe'er, G. et al. 2013. A protocol for better design, application and communication of population viability analyses. Conservation Biology 27: 644-656. https://doi. org/10.1111/cobi.12076

Pianka, E.R. 1970. On r and K selection. The American Naturalist 104: 592-597. https://doi.org/10.1086/282697

Porfírio, G. O. et al. 2012. New records of giant armadillo Priodontes maximus (Cingulata: Dasypodidae) at Serra do Amolar, Pantanal of Brazil. Edentata 13: 72-75. https://doi.org/10.5537/020.013.0110

Quiroga, V.A., Y.E. Di Blanco, A. Noss, A.J. Paviolo \& M.S. Di Bitetti. 2017. The giant armadillo (Priodontes maximus) in the Argentine Chaco. Mastozoología Neotropical 24: 163-175.

Radchuk, V., S. Oppel, J. Groeneveld, V. Grimm \& N. Schtickzelle. 2016. Simple or complex: relative im- pact of data availability and model purpose on the choice of model types for population viability analyses. Ecological Modelling 323: 87-95. https://doi. org/10.1016/j.ecolmodel.2015.11.022

Rivero, K., D.I. Rumiz \& A.B. Taber. 2005. Differential habitat use by two sympatric brocket deer species (Mazama americana and M. gouazoubira) in a seasonal Chiquitano forest of Bolivia. Mammalia 69: 169-183. https://doi.org/10.1515/mamm.2005.015

Rumiz, D.I. et al. 2002. La biodiversidad de la Estancia San Miguelito, Santa Cruz, Bolivia: una justificación para establecer reservas privadas de conservación. Ecología en Bolivia, Documentos, Serie Biodiversidad 1: 1-68.

Speakman, J.R. 2005. Body size, energy metabolism and lifespan. Journal of Experimental Biology 208: 1717-1730. https://doi.org/10.1242/jeb.01556

Silveira, L., A.T.A. Jácomo, M.M. Furtado, N.M. Torres, R. Sollmann \& C. Vynne. 2009. Ecology of the giant armadillo (Priodontes maximus) in the grasslands of Central Brazil. Edentata 8-10: 25-34. https://doi. org/10.1896/020.010.0112

ZIMS - Zoological Information Management System. 2021. Species360 Zoological Information Management System. https://zims.species360.org. Accessed on 31 March 2021.

Received: 19 April 2021; Accepted: 20 May 2021 